adopted in the UK. In 1977, however, this criterion was again recommended in the USA, possibly to protect medical practitioners against litigation.

Both the American and British codes recommend that the decision to withhold artificial respiration should be made by two doctors, and we follow the same procedure at our hospital. A further advantage of the British code is the detailed recommendation on how the arrest of spontaneous respiration should be verified. The most complete procedure, however, is that recommended by the Swedish Medical Society. ${ }^{6}$ These criteria include unresponsive coma, apnoea, isoelectric electroencephalogram, and non-filling of the cerebral vasculature after two aortocranial injections of contrast medium 25 minutes apart. Although this procedure is the most accurate, technical limitations may prevent it from being widely used.

After seven years of use the Finnish code seems to be suitable for general application. Nevertheless, the consultant anaesthetist was asked to confirm the diagnosis in fewer than two-thirds of the cases. We believe that if the code gives no instructions on how the arrest of spontaneous respiration should be verified an anaesthetist should be consulted in all cases of suspected brain death. Furthermore, in a third of our patients the diagnosis of brain death did not influence management. These patients died within a day, and the relatives might have been spared from further emotional distress if support had been withdrawn when the diagnosis was established. As soon as it is obvious that the patient cannot recover life-supporting measures should perhaps be withdrawn, since continued support may increase reluctance to embark on resuscitative measures generally. ${ }^{8}$ Moreover, the hospital's capacity to give active treatment to patients with a better prognosis is reduced, especially when only a few beds are available for intensive care.

The diagnosis of brain death should be based on a reliable clinical examination. Incorrect identification of the basic cause may still occur, as it did in three cases in the present series-one case of subarachnoid haemorrhage was diagnosed as subdural haematoma and another as intoxication, while in the third case intracerebral haemorrhage was incorrectly identified as cerebral abscess. The greatest risk seems to be in differentiating between intoxication and brain death. Intoxicated patients are often seen at our hospital, but the question of brain death is seldom raised. We have found that the criteria included in the Finnish code are sufficiently accurate to distinguish between patients who have a chance of even partial recovery and those who have not.

\section{References}

${ }^{1}$ Committee of Harvard Medical School, Fournal of the American Medical Association, 1968, 205, 337.

2 Conference of Medical Royal Colleges and their Faculties, British Medical Fournal, 1976, 2, 1187.

3 National Board of Health, Circular No 1508. Finland, 24 March 1971.

${ }^{4}$ Beecher, H K, New England fournal of Medicine, 1969, 281, 1070.

${ }^{5}$ Collaborative Study. Fournal of the American Medical Association, 1977, 237, 982 .

${ }^{6}$ Ingvar, D H, and Widén, L, Läkartidningen, 1972, 69, 3804.

7 Walker, A E, and Molinari, G F, Transactions of the American Neurological Association, 1975, 100, 29.

8 Jennet, B, Resuscitation, 1976, 5, 49.

(Accepted 15 November 1978)

\title{
Prescription for a better British diet
}

\author{
R PASSMORE, DOROTHY F HOLLINGSWORTH, JEAN ROBERTSON
}

British Medical fournal, 1979, 1, 527-531

\section{Summary and conclusions}

A new approach to establishing an upper or prescriptive level of recommended intakes of nutrients was devised for use in Britain. It was based on present food supplies in the UK, and the following measures were proposed to improve the national diet: moderate reductions in intakes of fat, sugar, meat, and alcohol; increased intakes of cereals, potatoes, and other vegetables and fruit; while intakes of milk and eggs and fish, pulses, and nuts were to remain unchanged. The proportions of food energy derived from protein would be increased, despite reduced meat consumption. Nutrient content of the diet may be expressed in terms of food groups or as nutrient concentrations per energy unit, which is particularly applicable

University of Edinburgh, Edinburgh EH8 9AG

R PASSMORE, MD, FRCPED, reader in physiology

Institute of Biology, 41 Queen's Gate, London SW7 5HU DOROTHY F HOLLINGSWORTH, OBE, BSC, secretary general

London NW11

JEAN ROBERTSON, BSC, SRD, nutritionist to planning or prescribing diets for individuals or small groups.

The suggested changes in the national diet are large enough to be meaningful, yet would not disrupt agricultural or trade policies if implemented over the next decade. Furthermore, the methods used to assess the recommended intakes of nutrients are flexible enough to be used both for planning and prescribing diets and for evaluating results of dietary surveys or histories.

\section{Introduction}

Nutritionists and dietitians often assess the adequacy of a diet by comparing the nutrients that it contains against tables of recommended intakes. In Britain the standards used were formerly those recommended by the Committee on Nutrition of the British Medical Association. ${ }^{1}$ These have now been superseded by the Recommended Intakes of Nutrients for the United Kingdom, published by the Department of Health and Social Security in 1969.2 This report states that "The recommendations may be used as guides for caterers and dietitians when planning diets for groups of healthy individuals. They may also be used in the evaluation of surveys of food consumption, and so in the identification of potential nutritional problems which merit further investigation."

In our opinion, a single set of recommendations cannot fulfil both these purposes adequately. We present an alternative approach to prescribing nutritionally acceptable diets. 


\section{Disadvantages of present recommendations}

The present recommended intakes of nutrients, except for energy, were defined as "the amounts sufficient or more than sufficient for the nutritional needs of practically all healthy persons in a population." They were derived so far as possible from experimentally determined physiological requirements of people of different ages, sex, and physical activity, after the addition of suitable safety factors. The energy recommendation contains no added safety factor, because any dietary energy intake in excess of individual physiological needs leads to obesity.

The difficulty lies in assessing the safety factor. In theory it may be taken as two standard deviations of the mean requirement, so that if individual requirements are normally distributed the recommendation covers the needs of $97.5 \%$ of a given population. In practice, however, since the distribution of individual requirements is not accurately known, a much larger safety factor is usually applied. In so far as this means that any individual obtaining the intake recommended is not at risk of deficiency, such recommendations certainly form a basis for prescribing nutritionally adequate diets. They are much less suitable for evaluating surveys of food consumption, for the average intakes of a group might not only fall well below the recommendations, but individual intakes might also be below them, without anyone consuming less than his or her individual requirement.

If there were separate recommendations for prescription and evaluation, as there are already in the UK for protein, ${ }^{2}$ each would become more useful. Recommendations for minimal safe intakes, based on physiologically determined needs, are generally applicable to people throughout the world, and are therefore best set by an international body such as the World Health Organisation or the Food and Agriculture Organisation of the United Nations. But recommendations for use by caterers, dietitians, and housewives when prescribing or planning diets and menus might well differ from country to country and be related to the tastes and dietary habits of the people and to available food supplies. These distinctions have already been discussed and amplified by Truswell. ${ }^{3}$

\section{Approach for prescribing diets in Britain}

A start should be made from those foods that healthy people in Britain already choose to eat. Our present diets are by no means perfect, and we recommend certain changes that would increase their nutritional quality while allowing traditional dietary patterns to be maintained. The suggested changes are large enough to be meaningful, yet not so large that they would disrupt our agricultural or trade policies if implemented over the next decade. Indeed, some are occurring already. These recommendations are made first in terms of foods or groups of foods, but may be converted into terms of nutrients, which may often be more practical. The nutrient content of the recommended diet may then be used as a standard at which to aim.

It should be emphasised that if the intake of a nutrient by a group or individual is below the prescriptive recommendation there is not necessarily any cause for concern. Clinical or biochemical investigations might be required only if intakes are below a lower, safe or diagnostic level.

\section{Is there a national diet?}

We must first consider the foods now eaten by different groups of people in Britain before deciding whether it is practicable to think in terms of a national diet. Certainly this would not have been possible before the second world war. Boyd Orr, in his book Food, Health and Income, ${ }^{4}$ showed that in the $1920 \mathrm{~s}^{2}$ and 30 s the poorest $10^{\circ} \%$ of the population were eating diets quite different from those in richer households and obtaining substantially less than the (then) estimated physiological requirements for protein and some minerals and vitamins; obvious undernutrition was then common in poor families. This was, however, rapidly remedied by wartime food policies that ensured a more equitable distribution of the limited food supply to everyone according to physiological need. ${ }^{5}$

After the war the poorer sections of the community continued to be able to obtain diets that were similar to those chosen by richer people and of roughly the same nutritional quality. Few people nowadays do not have a nourishing diet, and the differences in the intakes of nutrients between rich and poor, small and large families, and the various regions of Britain are now small. Furthermore, family size affects intakes of nutrients more than income, but this tends largely to reflect the smaller appetites of the children. This is shown by information obtained by the National Food Survey (NFS), which was started in 1940 and has continued ever since. The survey records the amounts of foods bought by housewives in representative households throughout Britain, and calculates the nutrient content, as described in annual reports. " Table I shows some typical values for 1977. Greater variations appear, of course, if the components of these groups of foods, such as the different meat products and individual fruits or vegetables, are examined more closely, but most of the enormous differences recorded by Boyd Orr and included in table I for comparison no longer exist.

\section{What is the present national diet?}

The present national diet is best described by reference to the total food supplies in the UK (known as consumption levels estimates (CLE) $^{8}$ which, like the NFS, started in 1940 and are published annually). The estimates are derived from statistics of agricultural production and imports, with allowances for exports and non-food uses, and correspond roughly to the food that is available for human consumption, while the NFS records are more equivalent to food as it enters the family kitchen. The amounts of foods in the CLE are greater than in the NFS, partly because they include foods prepared outside the home and eaten in catering establishments and as snacks, which are not recorded in the domestic survey, and partly because the food which is inevitably wasted during distribution will not be included in the NFS. Another difference is that the CLE figures are less detailed-for example, the variety of bakery goods is simply estimated as the component flour (and sugar and fat where appropriate).

CLE data are used to quantify our recommendations for two main reasons. First, CLE includes all foods which are available for eating, while the NFS, being a household survey, does not record drinks or food consumed outside the home. Secondly, when diets are to be prescribed for large groups of people as in schools or hospitals, descriptions should be made at the wholesale or retail rather than the household level. Table II shows the amounts of the 11 major groups of foods and of alcoholic beverages that were on average available during 1973-7. This is taken as our present national diet. The table also shows the target for the recommended changes.

\section{Improvements in the present diet}

The changes that we thought likely to increase the overall nutritional quality of the national diet are as follows.

Decreased consumption of fats and oils (by $15^{\circ}{ }_{0}$ ); sugar (by $15^{\circ}{ }_{0}$ ); meat (by $15^{\circ}$ ) (this reduction is not incompatible with improvements in nutritional quality, but has been introduced for other reasons (see below)); alcohol (by $25^{\circ}{ }_{0}$ ).

Increased consumption of potatoes (by $15 \%$ ); other vegetables (by $15_{0}^{\circ}$ ); fruit (by $15 \%$ ); grain products (by $20 \%$ ).

No change in consumption of dairy products (excluding butter); fish; eggs; pulses (and nuts).

We believe that changes of this magnitude are neither excessive nor impossible to achieve in the UK within the next decade. We now explain why these changes should bring about an overall improvement in nutrition and health.

\section{REDUCTION IN VISIBLE FATS}

Since the second world war the proportion of energy derived from fat in the diet has increased insidiously. This trend has been associated with an increased incidence of coronary heart disease and there is considerable, though not conclusive, evidence that a high fat intake contributes to this disease. In line with opinion in many other countries, the DHSS report on Diet and Coronary Heart Disease ${ }^{9}$ recommended that "the amount of fat in the United Kingdom diet, especially saturated fat from both animal and plant sources, should be reduced." Our target is compatible with this recommendation, and is also in line with the recommendation of the Joint Working Party of the Royal College of Physicians and the British Cardiac Society. ${ }^{10}$ Reduction in fat consumption might also help to reduce the incidence of certain cancers. ${ }^{11}$ 
TABLE I-Quantities of major foods purchased by households in selected regions, income groups, and family compositions in 1977 based on information from National Food Survey (NFS), and a comparison with the 1930s. Amounts expressed in units/person/week

\begin{tabular}{|c|c|c|c|c|c|c|c|c|c|c|}
\hline & \multicolumn{8}{|c|}{ NFS, 1977} & \multicolumn{2}{|c|}{ Boyd Orr, 19364 } \\
\hline & \multicolumn{3}{|c|}{ Region } & \multicolumn{3}{|c|}{ Family size } & \multicolumn{2}{|c|}{ Income group } & \multirow{2}{*}{$\begin{array}{c}\text { Income } \\
\text { group VI+ }\end{array}$} & \multirow{2}{*}{$\begin{array}{c}\text { Income } \\
\text { group I }+\end{array}$} \\
\hline & $\begin{array}{l}\text { Greater } \\
\text { London }\end{array}$ & Scotland & Wales & $\begin{array}{l}2 \text { Adults; } \\
0 \text { children }\end{array}$ & $\begin{array}{l}2 \text { Adults; } \\
2 \text { children }\end{array}$ & $\begin{array}{l}2 \text { Adults : } 4 \text { or } \\
\text { more children }\end{array}$ & $\begin{array}{c}\text { Income } \\
\text { group A* }\end{array}$ & $\begin{array}{c}\text { Income } \\
\text { group D* }\end{array}$ & & \\
\hline 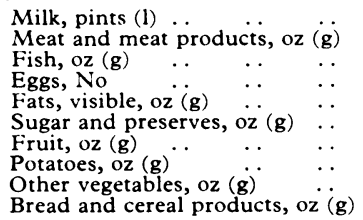 & $\begin{aligned} & 4(2 \cdot 3) \\
& 42(1191) \\
& 5(141) \\
& 4( \\
& 11(312) \\
& 13(369) \\
& 30(850) \\
& 39(1106) \\
& 42(1191) \\
& 54(1531)\end{aligned}$ & $\begin{aligned} & 5(2 \cdot 8) \\
& 38(1077) \\
& 4(113) \\
& 4 \\
& 10(283) \\
& 15(425) \\
& 21(595) \\
& 43(1219) \\
& 31(879) \\
& 60(1701)\end{aligned}$ & $\begin{aligned} & 5(2 \cdot 8) \\
& 36(1021) \\
& 4(113) \\
& 4 \\
& 11(312) \\
& 15(425) \\
& 25(709) \\
& 37(1049) \\
& 40(1134) \\
& 59(1673)\end{aligned}$ & $\begin{aligned} & 5(2 \cdot 8) \\
& 47(1332) \\
& 5(141) \\
& 5 \\
& 13(369) \\
& 17(482) \\
& 31(879) \\
& 41(1162) \\
& 51(1446) \\
& 63(1786)\end{aligned}$ & $\begin{aligned} & 5(2 \cdot 8) \\
& 32(907) \\
& 3(85) \\
& 3 \\
& 10(283) \\
& 13(369) \\
& 20(567) \\
& 39(1106) \\
& 36(1021) \\
& 52(1474)\end{aligned}$ & $\begin{aligned} & 4(2 \cdot 3) \\
& 25(709) \\
& 3(85) \\
& 4 \\
& 9(255) \\
& 15(425) \\
& 15(425) \\
& 39(1106) \\
& 29(822) \\
& 58(1644)\end{aligned}$ & $\begin{aligned} & 5(2 \cdot 8) \\
& 43(1219) \\
& 4(113) \\
& 4 \\
& 10(283) \\
& 12(340) \\
& 33(936) \\
& 29(822) \\
& 41(1162) \\
& 49(1389)\end{aligned}$ & $\begin{array}{l}4(2 \cdot 3) \\
39(1106) \\
4(113) \\
4(1340) \\
12(340) \\
17(482) \\
17(482) \\
52(1474) \\
43(1219) \\
65(1843)\end{array}$ & $\begin{array}{l}6(3.4) \\
49(1389) \\
14(397) \\
5 \\
16(454) \\
25(709) \\
39(1106) \\
54(1531) \\
34(934) \\
60(1701)\end{array}$ & $\begin{aligned} & 1(0 \cdot 6) \\
& 23(652) \\
& 3(85) \\
& 2 \\
& 10(283) \\
& 18(510) \\
& 14(397) \\
& 53(1503) \\
& 16(454) \\
& 66(1871)\end{aligned}$ \\
\hline
\end{tabular}

*More than $£ 110$ and less $£ 40$ per week representing highest $10^{\prime \prime}$., and lowest $7^{\circ}$ ", of incomes earned by heads of households.

+More than $£ 4.50$ and less than 50 p per head per week representing highest and lowest $10^{\circ}$ ". of incomes.

TABLE II-Total food supplies 1973-7 and target figures for recommended changes. Amounts are $\mathrm{kg} /$ person/year, except where stated otherwise

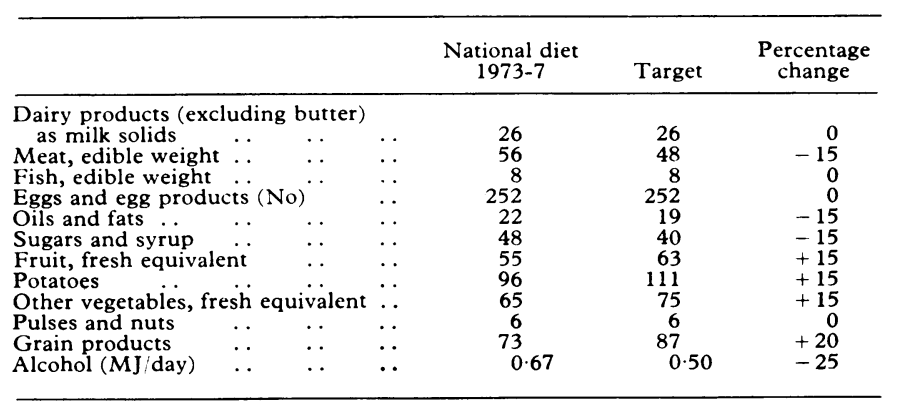

Conversion: SI to traditional units $-4 \cdot 2 \mathrm{MJ} \approx 1000 \mathrm{kcal}$.

\section{REDUCTION IN SUGAR INTAKE}

The consumption of sucrose increased steadily for two centuries until about 1958, except for interruptions during the two world wars, but has now begun to drop slightly. The reduction recommended would probably decrease the prevalence of dental caries, and possibly decrease the prevalence of obesity. The energy content of refined sugar is not accompanied by other nutrients, and some people also believe that a high intake of sugar contributes to diabetes and to coronary heart disease. We therefore agree that the health of the community would be improved if we ate less sugar.

\section{REDUCTION IN MEAT}

Meat is one of the most valuable components of the diet, but present consumption by most sections of the community may be considered as a "luxury" that is becoming increasingly difficult to justify in terms of the world's resources, especially of food and animal feeding stuffs. Although total meat at present provides a quarter of the saturated fatty acid content of the British diet, it is also a rich source of many minerals, especially iron and $B$ vitamins; nevertheless the well-being of vegetarians and of people who already choose to eat little meat shows that a reduction of $15 \%$ should have no adverse effect on health.

\section{REDUCTION IN ALCOHOLIC DRINKS}

The quantities of beer, wines, and spirits drunk have all risen steadily in the past 20 years. The main nutritional contribution of these drinks is energy, and excessive alcohol consumption has many other undesirable effects; we therefore recommend a reduction in consumption, so that these drinks provide no more energy on average than they did in the 1960 s. Even then they would still add $4^{\circ}{ }_{0}$ to the energy content of the national diet.

\section{INCREASED CONSUMPTION OF POTATOES}

Consumption of fresh potatoes has been falling, although this has been partially offset by an increase in potato products. Potatoes are a good and comparatively cheap home-produced source of protein, dietary fibre, and many nutrients, especially vitamin $C$, and we therefore recommend an increase in their use.

\section{INCREASES IN OTHER VEGETABLES AND FRUIT}

This would increase our intakes of several vitamins and minerals but, except perhaps for folate, is unlikely to be of great nutritional importance in a diet already well endowed. Also important would be the associated increase in dietary fibre, for more than $30 \%$ of the present intake comes from these sources. ${ }^{12}$ This would lead to a reduction in constipation and may also reduce the incidence of some diseases of the large bowel.

\section{INCREASE IN GRAIN PRODUCTS}

Consumption of wheat (mainly in the form of bread) has fallen steadily for many years, yet bread still remains a principal item of our diet. It is rich in many nutrients, and an increase in its use is a simple and satisfactory way of making good the decrease in energy resulting from the reductions in fat, sugar, and meat. (If meat consumption were not decreased wheat consumption need increase by only $10 \%$ to bring the energy content of the diet back to $3000 \mathrm{kcal}(12 \cdot 6 \mathrm{MJ}) /$ day). Though wheat is the major cereal consumed in the UK, other cereals such as oatmeal are also nutritious and can be grown in Britain. They should be included in the increased consumption.

\section{MILK AND EGGS}

These traditional foods have been recommended for many generations as good for health, and both are good sources of many nutrients. Recently, however, some nutritionists have changed their minds because of evidence that high dietary intakes of saturated fatty acids and cholesterol may be a cause of coronary artery diseases. Thus they consider that consumption of whole milk and eggs by adults should be reduced. We do not believe, however, that these foods in the amounts normally consumed in the UK are detrimental to health, although some people with specific diseases will have to restrict their intakes of these and indeed other foods. Because of their many excellent nutritional properties, we should like to see present intakes of milk and eggs maintained but have no reason to advocate an increase.

\section{FISH, PULSES, AND NUTS}

These pleasant and nutritious foods have a relatively small place in our national diet. We should like to see consumption maintained at the present level, but consider that it would be unrealistic to recommend appreciable increases.

\section{Changes in sources of energy and improvement in nutritional value}

A consequence of the changes recommended is that, in our better British or target diet, the proportions of food energy derived from protein would be greater than at present, despite the reduction in meat. 
Intakes of starch and dietary fibre would also be increased, while the proportion of energy derived from fat, sucrose, and alcohol would be reduced (table III). These changes are all compatible with the recent recommendations of the DHSS. ${ }^{13}$ Most ways in which wheat is eaten also include fat - for example, cakes, biscuits, and bread and butterand when the diet during and after the second world war included large amounts of cereals and comparatively little fat, it was thought to be unpalatable. We envisage no such difficulty with our recommendations, however, for the scale of the changes is much less (see table IV).

In table $\mathrm{V}$ the energy, mineral, and vitamin contents in the present and target diets are compared. Not only has the total energy supply been allowed to decrease slightly (by $0.6 \mathrm{MJ}$ per person per day) but the amount of every mineral and vitamin shown except for the fatsoluble vitamins (vitamins $\mathrm{A}$ and $\mathrm{D}$ ) would remain steady or even be increased. Diets in Britain already provide more than the present recommended intakes of most nutrients and about double the recommended amount of vitamin A. And the absolute nutritional quality of the target diet in terms of nutrients per $M J$ is even better than at present (table VI).

In summary, in the target diet some of the foods commonly said to be sources of "empty calories" (fat, sugar, and alcohol) are replaced by those rich in protein, minerals, vitamins, and fibre. In addition, the effect of a reduced consumption of meat has been included. The changes are in agreement with current recommendations about nutrition education in this and other countries. Furthermore, Allaby et $a l^{14}$ have shown that changes similar to those we recommend would have little effect on agricultural practice in the UK, for many could be achieved through reductions in the foods we now import.

\section{Prescribing diets}

So far, the amounts of food we recommended are applicable only to the nation as a whole. There are two ways in which the recommendations could be made more useful for prescribing diets for smaller groups of people, such as those in schools and hospitals, or even members of a family. Firstly, the total amounts of food could be simply converted from kilograms per person per year to the more practical level of ounces per person per week. We think that this would often be too restricting, for it might imply that each person ought to consume the specified amount of fruit or fat (or even alcoholic drinks), regardless of whether they had previously been eating more or less.

TABLE III-Sources of food energy derived from national diet, 1973-7, and target figures for better British diet. Figures expressed as percentages of total energy intake

\begin{tabular}{llccccc}
\hline & & Protein & Fat & Carbohydrate & Alcohol \\
\hline National diet & $1973-7 \ldots$ & $10 \cdot 8$ & $38 \cdot 0$ & $46 \cdot 0$ & $5 \cdot 2$ \\
Target diet & $\ldots$ & $\ldots$ & $11 \cdot 3$ & $34 \cdot 9$ & $49 \cdot 7$ & $4 \cdot 0$
\end{tabular}

TABLE IV-Availability of wheat flour and visible fat in selected years, and target figures for better British diet (expressed as kg/person/year)

\begin{tabular}{lllllccc}
\hline & & & & & & & \\
& & & & & 1947 & $1973-7$ & $\begin{array}{c}\text { Better } \\
\text { British diet }\end{array}$ \\
\hline $\begin{array}{l}\text { Wheat flour } \\
\text { Visible fat }\end{array}$ & $\ldots$ & $\ldots$ & $\ldots$ & $\ldots$ & 110 & 64 & $79^{*}$ \\
Ratio fat:flour & $\cdots$ & $\ldots$ & $\cdots$ & $\cdots$ & 16 & 22 & 19 \\
& & & & & $1: 7$ & $1: 3$ & $1: 4$ \\
\hline
\end{tabular}

*Assuming that all increase in cereal production is wheat flour.
TABLE VI-Nutrient concentrations in national diet 1973-7 and better British diet, per $M\}^{*}$

\begin{tabular}{|c|c|c|c|c|c|c|c|}
\hline & & & & & & $\begin{array}{c}\text { National diet } \\
1973-7\end{array}$ & $\underset{\text { diet }}{\text { Better British }}$ \\
\hline \multicolumn{8}{|l|}{ Protein $(g)$} \\
\hline Fat $(\mathrm{g}) \quad \ldots$ & .. & $\therefore$ & $\because$ & $\because$ & $\because$ & 10 & 9 \\
\hline Carbohydrate $(\mathrm{g})$ & $\therefore$ & $\because$ & $\because$ & $\therefore$ & $\therefore$ & 29 & 32 \\
\hline Calcium (mg) & $\ldots$ & $\ldots$ & $\therefore$ & $\ldots$ & $\because$ & 87 & 94 \\
\hline Iron (mg) & $\ldots$ & $\ldots$ & $\therefore$ & $\therefore$ & .. & 1.0 & 1.1 \\
\hline Thiamine $^{+}(\mathrm{mg})$ & .. & $\because$ & . & $\ldots$ & $\because$ & $0 \cdot 10$ & 0.12 \\
\hline Riboflavine (mg) & $\therefore$ & & . & $\because$ & 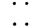 & $0 \cdot 15$ & 0.15 \\
\hline \multicolumn{3}{|c|}{ Nicotinic acid equivalent $(\mathrm{mg})$} & & $\because$ & $\because$ & 2.5 & $2 \cdot 6$ \\
\hline \multicolumn{3}{|c|}{$\begin{array}{l}\text { Nicotinic acid equivalent (mg) } \\
\text { Vitamin } C_{+}^{+}(\mathrm{mg})\end{array}$} & . & $\because$ & $\because$ & $4 \cdot 1$ & $\begin{array}{l}2.6 \\
4.8\end{array}$ \\
\hline \multicolumn{3}{|c|}{ Retinol equivalent $(\mu \mathrm{g})$} & $\because$ & $\because$ & $\because$ & 102 & 101 \\
\hline
\end{tabular}

*Total energy includes that from alcohol.

$+20^{\prime \prime}$ " of total supply deducted to allow for cooking losses.

$\$ 75^{\prime \prime}$ ", deducted from that in vegetable and $50^{\prime \prime}$ ", from potatoes to allow for cooking losses.

Secondly, individuals or groups should be advised to include at least this content of essential nutrients in their diets. Because the foods eaten in any one family or other group would be similar, while the amount eaten by any individual depends on appetite, the nutrient content is best expressed in relation to energy - that is, as nutrient concentrations. These are given for the recommended diet in table VI.

\section{Practical application of recommendations}

These recommendations should be applied to any heterogeneous group of healthy people in the following ways. Firstly, their energy requirement, which depends on the age, sex, and level of physical activity of each member of the group, -2 must be met. Secondly, not less than $10^{\circ}{ }_{0}$ of this energy should be derived from protein, not more than $35^{\circ}{ }_{0}$ from fat, and not more than $14^{\circ}$, from total sugar (including that in cakes, sweets, etc). Thirdly, the nutrient concentrations of the minerals and vitamins should be at least those shown in table VI.

These recommendations are applicable to most groups of people, but additional factors should be taken into account for certain special groups.

Children up to 5 years of age should first be provided with at least $500 \mathrm{ml}$ milk each day, as should pregnant and lactating women. Older children and adolescents should be provided with $250 \mathrm{ml}$ of milk.

When the energy requirement is low (less than about $6 \mathrm{MJ} / \mathrm{day}$ $(1500 \mathrm{kcal} /$ day $))$ as will be the case for small children, some older or disabled people, and those on slimming diets, then additional fruit and vegetables as well as milk or cheese should be provided to ensure that vitamin $C$ intake reaches $30 \mathrm{mg} /$ day and the calcium intake reaches $500 \mathrm{mg} /$ day $(700 \mathrm{mg} /$ day for adolescent boys and girls).

When energy requirements are high (about $14 \mathrm{MJ} /$ day $(3300$ $\mathrm{kcal} /$ day)) intakes of nutrients are normally adequate, even if their concentrations fall somewhat below our recommendations. An increased consumption of cheaper foods and those providing empty calories is then acceptable, and helps to keep food costs within practical limits.

Iron-The recommendations do not meet the iron needs (up to $18 \mathrm{mg} /$ day) of the $5 \%$ to $10 \%$ of women who have heavy menstrual losses. It is seldom practical to meet this by dietary measures, so such women should be given a medicinal supple-

TABLE V-Nutrient content of national diet 1973-7 and target figures for better British diet (expressed in units/person/day)

\begin{tabular}{|c|c|c|c|c|c|c|c|c|c|c|c|c|}
\hline & $\begin{array}{l}\text { Energy } \\
\text { including } \\
\text { alcohol } \\
(\mathrm{MJ})\end{array}$ & $\begin{array}{l}\text { Protein } \\
(\mathrm{g})\end{array}$ & $\begin{array}{l}\text { Fat } \\
(\mathrm{g})\end{array}$ & $\underset{(\mathrm{g})}{\text { Carbohydrate }}$ & $\underset{(\mathrm{mg})}{\text { Calcium }}$ & $\begin{array}{l}\text { Iron } \\
(\mathrm{mg})\end{array}$ & $\begin{array}{c}\text { Retinol } \\
\text { equivalent } \\
(\mu \mathrm{g})\end{array}$ & $\underset{(\mathrm{mg})}{\text { Thiamine }}$ & $\begin{array}{c}\text { Riboflavine } \\
\text { (mg) }\end{array}$ & $\begin{array}{c}\text { Nicotinic } \\
\text { acid } \\
\begin{array}{c}\text { equivalent } \\
(\mathrm{mg})\end{array}\end{array}$ & $\underset{(\mathrm{mg})}{\mathrm{C}}$ & $\begin{array}{c}\text { Vitamin } \\
\text { D } \\
(\mu \mathrm{g})\end{array}$ \\
\hline $\begin{array}{l}\text { National diet } \\
\text { 1973-7 } \\
\text { Better British diet }\end{array}$ & $\begin{array}{l}12 \cdot 9 \\
12 \cdot 6\end{array}$ & $\begin{array}{l}83 \\
85\end{array}$ & $\begin{array}{l}130 \\
117\end{array}$ & $\begin{array}{l}380 \\
400\end{array}$ & $\begin{array}{l}1120 \\
1180\end{array}$ & $\begin{array}{l}13 \\
14\end{array}$ & $\begin{array}{l}1320 \\
1280\end{array}$ & $\begin{array}{l}1.7 \\
1.8\end{array}$ & $\begin{array}{l}1.9 \\
1.9\end{array}$ & $\begin{array}{l}32 \\
32\end{array}$ & $\begin{array}{l}100 \\
113\end{array}$ & $\begin{array}{l}2 \cdot 9 \\
2 \cdot 8\end{array}$ \\
\hline
\end{tabular}

Conversion: SI to traditional units $-4 \cdot 2 \mathrm{MJ} \approx 1000 \mathrm{kcal}$ 
ment. Similarly, pregnant women often require supplements of iron and folate in the last trimester to meet their high requirements for these nutrients.

When he was professor of nutrition and dietetics at Queen Elizabeth College, University of London, Professor A S Truswell took a full part in the discussions that have led to this paper. We thank him for the help that he gave us in preparing it before he left England to become professor of nutrition at the University of Sydney, Australia. We are also indebted to Dr D H Buss of the Ministry of Agriculture, Fisheries and Food. He, too, played an essential part in our discussions from the beginning, and in addition was responsible for the final calculations in the tables.

\section{References}

1 British Medical Association, Report of the Committee on Nutrition. London, BMA, 1950

2 Department of Health and Social Security, Recommended Intakes of Nutrients for the United Kingdom, Reports on Public Health and Medical Subjects No 120. London, HMSO, 1969.

3 Truswell, A S, Nutrition and Metabolism, 1977, 4, 224.
${ }^{4}$ Boyd Orr, J, Food Health and Income. London, Macmillan, 1936.

${ }^{5}$ Hollingsworth, D F, The Application of the Newer Knowledge of Nutrition, in Drummond, J C, and Wilbraham, A, The Englishman's Food, ed D F Hollingsworth, 2nd edn. London, Jonathan Cape, 1957.

${ }^{6}$ Ministry of Agriculture, Fisheries and Food, Household Food Consumption and Expenditure: 1975 With a Review of the Six Years 1970 to 1975. London, HMSO, 1977.

${ }^{7}$ Ministry of Agriculture, Fisheries and Food, Household Food Consumption and Expenditure: 1976. London, HMSO, 1977.

8 Angel, L J, and Hurdle, G E, Economic Trends No 294. London, HMSO, 1978.

${ }^{9}$ Department of Health and Social Security, Diet and Coronary Heart Disease, Report on Health and Social Subjects 7. London, HMSO, 1974.

10 Report of a Joint Working Party of the Royal College of Physicians of London and the British Cardiac Society, Fournal of the Royal College of Physicians, 1976, 10, 1.

${ }^{11}$ Enig, M M, Munn, R J, and Keeney, M, Federation Proceedings, 1978, 37, 2215.

12 Southgate, D A T, Bingham, S, and Robertson, J, Nature, 1978, 274, 52.

13 Department of Health and Social Security, Eating for Health. London, HMSO, 1978.

14 Allaby, A, Baldock, B, and Blythe, C, British Nutrition Foundation Nutrition Bulletin, 1977, 4, 12

(Accepted 25 October 1978)

\title{
How to do it . . .
}

\section{Talk to a reporter}

\author{
TONY SMITH
}

Doctors are mostly ambivalent about the press, radio, and television-and the reasons for their vacillation between admiration and loathing were well illustrated recently with the birth of the test-tube baby Louise Brown. The technical achievement was generally described clearly and accurately, so satisfying the natural curiosity of readers, listeners, and viewers; but there was also a disgraceful siege of the hospital for weeks on end, with reporters competing for exclusive rights to interview the parents (and other potential parents)-some using lies and confidence trickery in an attempt to extract confidential information from hospital staff.

Of course the public has a legitimate interest in hearing about medical advances, and often the best way for the story to be presented is with a "human interest" angle; but most doctors have heard horror stories about smooth-talking reporters who try to discover the identity of a patient who has a right to privacy, and many fear that if they talk to the press they may find an incautious comment given headline treatment.

\section{Ask for time}

How, then, should a doctor respond when his telephone rings and he finds a reporter (from the press, radio, or TV)

\section{British Medical Journal}

TONY SMITH, вM, BCH, deputy editor wanting to talk about a news story-either an incident concerning a particular patient or a technical advance of some kind? My first piece of advice is to ask for time. Few of us are practised enough at public speaking to think on our feet, and I find it invaluable to ask for a few minutes to put my thoughts together. In fact, I usually make a few notes of what I want to say. A 10-20 minute pause will give you time to check a few facts (what exactly is the incubation period of mumps?), possibly have a quick chat with a colleague, and, if you are in any doubt, to take advice. (What sort of advice? You may want to ask your hospital secretary whether he is issuing a press statement, and if so would he prefer doctors to refer all callers to him; or you may wish to discuss confidentiality with your defence society. If there is any possibility of litigation you should almost certainly say nothing without having first checked with the legal experts.)

So after 10 minutes the reporter rings back. At this point you may have decided to make no comment either on legal advice or because the subject (such as, say, AID in lesbians) is one which you'd prefer to avoid for fear of getting egg on your face. Don't explain why; simply apologise for wasting his time and say that having had time to think you have decided not to comment. Mostly, however, you'll want to do what you can to answer the questions. But next find out on what basis you are talking. Is the reporter simply seeking background information, talking off the record? Is he wanting attributable statements that will appear (or be heard) with your name attached ? Or is he sounding you out for a possible interview on TV or radio? The distinction is important, and it is up to you to ask, not the reporter to explain. If he is asking you for attributable comments on a news story then you should ask him to read out exactly what is going to be printed. If he tells you that he is still putting the story together, then ask him to phone you later with the 